\title{
Aplikasi Urease dari Biji Kacang Tolo (Vigna unguiculata ssp unguiculata L.) untuk Biosensor Urea
}

\section{Urease Application of Black-eyed Pea (Vigna unguiculata ssp unguiculata L.) for Urea Biosensor}

\author{
Zusfahair*, Dian Riana Ningsih, Amin Fatoni, Vika Aprillia Puspitarini \\ Jurusan Kimia Fakultas Matematika dan Ilmu Pengetahuan Alam, Universitas Jenderal Soedirman, Purwokerto \\ 53123 , Indonesia. \\ *Corresponding author : zusfahair@gmail.com
}

Received: August 2018; Revision: February 2019; Accepted: May 2019; Available online: May 2019

\begin{abstract}
Abstrak
Penggunaan urease dalam analisis urea yang digabungkan dengan suatu transduser disebut biosensor urea. Tujuan penelitian adalah menentukan kadar urea dengan metode biosensor urea berbasis urease biji kacang tolo yang diamobilisasi pada matrik alginat dan dideteksi secara kolorimetri menggunakan indikator bromtimol biru. Penelitian dimulai dengan isolasi urease dari biji kacang tolo (Vigna unguiculata ssp unguiculata L.), kemudian diamobilisasi menggunakan metode penjebakan dengan natrium alginat, setelah mencampur larutan urease dengan natrium alginat, diteteskan dalam larutan $\mathrm{CaCl}_{2}$ sampai terbentuk urease alginat. Beads urease alginat direaksikan dengan urea menghasilkan ion amonium, selanjutnya ditambahkan indikator bromtimol biru dan perubahan warnanya diukur menggunakan spektrofotometer. Kinerja analitis biosensor urea ditentukan melalui penentuan waktu reaksi enzimatis, keberulangan analisis, keberulangan pembuatan dan pengujian senyawa penganggu dengan konsentrasi urea $4 \mathrm{mM}$, serta penentuan linearitas, batas deteksi, dan batas kuantifikasi dengan konsentrasi urea $0.05 ; 1 ; 3 ; 7$; dan $15 \mathrm{mM}$. Hasil penelitian menunjukkan beads urease alginat bisa digunakan berulang sampai 8 kali. Kinerja analitis beads urease alginat menghasilkan respon yang linier pada rentang 0.05-15 mM dengan koefisien korelasi sebesar 0.9981, batas deteksi sebesar $0.8 \mathrm{mM}$ dan batas kuantifikasi sebesar $2.67 \mathrm{mM}$. Keberulangan pembuatan beads urease alginat menghasilkan nilai koefisien variasi sebesar $6 \%$. Analisis tidak terganggu dengan keberadaan asam askobat $0.05 \mathrm{mM}$ dan asam urat $0.4 \mathrm{mM}$.
\end{abstract}

Kata kunci: Amobilisasi urease, beads alginat, biosensor, biji kacang tolo, spektrofotometri.

\begin{abstract}
The use of urease in the urea analysis which combined with a transducer is called urea biosensor. Research aimed to determine urea level using urea biosensor method based on urease from black-eyed pea that immobilized on alginate matrix and detected by colorimetric using bromothymol blue indicator. The research began with urease isolation from black-eyed pea (Vigna unguiculata ssp unguiculata L.), and then it immobilized utilizing the trapping method with sodium alginate, after mixing urease solution with sodium alginate, it is dripped in $\mathrm{CaCl}_{2}$ solution until alginate urease beads formed. Alginate urease beads reacted with urea to produce ammonium ion, then it's added with indicator bromothymol blue, and the color changes were measured using a spectrophotometer. The analytical performance of urea biosensor is determined by enzymatic reaction time, repeated analysis, repeatability of fabrication and calibration of disturbing compound with concentration of urea $4 \mathrm{mM}$, also linearity, limit of detection and limit of quantification with concentration of urea $0.05,1,3,7$ and $15 \mathrm{mM}$. The results showed that alginate urease beads could repeatedly be used until eight times. The analytical performance of alginate urease beads including a linear response in the range of $0.05 \mathrm{mM}$ $15 \mathrm{mM}$ with the correlation coefficient of 0.9981 , the detection limit of $0.8 \mathrm{mM}$ and the quantification limit of $2.67 \mathrm{mM}$. The repeatability of fabrication alginate urease beads produced the coefficient of variation value of $6 \%$. The presence of $0.05 \mathrm{mM}$ ascorbic acid and $0.4 \mathrm{mM}$ uric acid.was not disrupted the analysis.
\end{abstract}

Keywords: urease immobilization, alginate beads, biosensor, black-eyed pea, spectrophotometry.

DOI: $10.15408 / j k v \cdot v 5 i 1.8776$ 


\section{PENDAHULUAN}

Urea adalah salah satu produk metabolisme protein. Peningkatan urea dalam darah menunjukkan adanya penyakit ginjal, batu di saluran kemih atau bahkan tumor kandung kemih, sedangkan penurunan kadar urea menunjukkan adanya kerusakan yang parah pada hati. Kadar normal urea dalam serum berkisar dari $15 \mathrm{mg} / \mathrm{dL}$ sampai $45 \mathrm{mg} /$ dL (2.5 mM sampai $6.7 \mathrm{mM}$ ) (Saeedfar et al., 2013). Analisis kadar urea dalam darah secara rutin penting dilakukan untuk mengetahui kondisi fungsi organ-organ tersebut.

Analisis urea menggunakan senyawa biologis (enzim) yang digabungkan dengan suatu transduser dikenal dengan nama biosensor. Menurut (Yi et al., 2014), biosensor bekerja berdasarkan amobilisasi dari suatu komponen biologi (enzim, bakteri, dan lain - lain) pada matriks membran polimer yang diintegrasikan dengan sinyal tranduser pada analit. Dengan demikian akan dihasilkan sinyal elektrik yang proporsional terhadap konsentrasi analit.

Oleh karena itu, penting untuk mengembangkan matrik pendukung amobilisasi enzim yang akan diimplementasikan pada biosensor, sehingga dapat meningkatkan pemakain berulang (Fatoni et al., 2014). Penentuan kadar urea, bisa menggunakan biosensor dengan enzim urease. Urease ditemukan melimpah pada beberapa jaringan tanaman, terutama bagian biji dari beberapa anggota keluarga Fabaceae (suku polong-polongan) dan Cucurbitaceae (suku labu-labuan).

Enzim urease telah diisolasi dari biji kacang tolo (Zusfahair et al., 2018). Ketersediaan biji kacang tolo melimpah namun pemanfaatannya kurang oleh karena itu dapat dimanfaatkan sebagai bahan sumber enzim urease. Urease yang diisolasi dari biji kacang tolo selanjutnya diamobilisasi sehingga diperoleh urease amobil. Urease amobil digunakan sebagai senyawa pendeteksi pada biosensor urea. Beberapa peneliti telah melakukan penentuan kadar urea menggunakan biosensor dengan senyawa pendeteksi enzim urease yang diamobilisasi pada berbagai matrik pendukung, seperti penggunaan: $\mathrm{ZnO}$ (Eghbali dan Farahbakhsh, 2015); nanomaterial fullerene (Saeedfar et al., 2013); dan nilon (Verma et al., 2012).
Pada penelitian ini dilakukan amobilisasi enzim urease dari biji kacang tolo menggunakan matrik pendukung alginat dengan metode penjebakan sehingga terbentuk beads urea alginat. Beads urease alginat direaksikan dengan urea menghasilkan ion amonium. Selama ini pengukuran kadar amonium dengan metode spektrofotometri dapat menggunakan reagen Nessler. Reagen Nessler mahal dan berbahaya untuk kesehatan sehingga diperlukan pengembangan metode lain untuk menentukan kadar urea. Salah satu metode alternatif untuk mengukur kadar amonium adalah dengan menggunakan indikator $\mathrm{pH}$ yang murah dan ramah lingkungan yang dapat menghasilkan perubahan warna seperti bromtimol biru (BTB). BTB adalah indikator asam-basa yang banyak digunakan. Larutan BTB menunjukkan warna kuning dalam larutan asam lemah, dan berubah menjadi biru melalui hijau pada peningkatan $\mathrm{pH}$ (Shimada dan Hasegawa, 2017). Dalam biosensor urea, urease mengkatalis hidrolisis urea untuk membentuk $\mathrm{CO}_{3}^{-2}$ dan $2 \mathrm{NH}_{4}^{+}$. Berikut persamaan reaksi hidrolisis urea oleh enzim urease (Kale et al., 2016):

\section{$\mathrm{NH}_{2} \mathrm{CONH}_{2}+2 \mathrm{H}_{2} \mathrm{O} \longrightarrow \mathrm{CO}_{3}^{-2}+2 \mathrm{NH}_{4}^{+}$}

Reaksi ini menyebabkan peningkatan $\mathrm{pH}$ dan menggeser keseimbangan BTB ke bentuk yang lebih basa sehingga menyerap cahaya pada Panjang gelombang $620 \mathrm{~nm}$ (Xie dan Suleiman, 1990). Nilai absorbansi larutan hasil reaksi enzimatis dapat diukur dengan spektrofotometer. Performansi analitik biosensor urea ditentukan melalui penentuan waktu reaksi enzimatis, linearitas dan batas deteksi dan batas kuantifikasi, keberulangan analisis, keberulangan pembuatan dan pengujian senyawa penganggu (Ravisankar et al., 2015).

\section{METODE PENELITIAN Alat dan Bahan}

Alat-alat yang digunakan dalam penelitian adalah alat-alat yang umum digunakan di Laboratorium Biokimia ditambah alat penunjang seperti neraca analitik (Ohaus), $\mathrm{pH}$ meter (Hanna Instrument), lemari pendingin $(L G)$, inkubator, sentrifuge (Quantum), kuvet dan spektrofotometer UVVis (Shimadzu UV-1800). 
Bahan yang digunakan dalam penelitian adalah biji kacang tolo. Determinasi biji kacang tolo yang digunakan adalah famili: Fabaceae, genus: Vigna, dan spesies: Vigna unguiculata ssp. unguiculata L. (Vigna unguiculata ssp unguiculata L.) bibit yang dibeli dari Pasar Wage Purwokerto, alginat, akuades, kapas, aseton, sodium dihidrogen fosfat $\left(\mathrm{NaH}_{2} \mathrm{PO}_{4}\right)$ (Merck, Jerman), disodium hidrogen fosfat $\left(\mathrm{Na}_{2} \mathrm{HPO}_{4}\right)$ (Merck, Jerman), urea, ammonium hidroksida $\left(\mathrm{NH}_{4} \mathrm{OH}\right)$ (Merck, Jerman), natrium asetat $\left(\mathrm{CH}_{3} \mathrm{COONa}\right)$ (Merck, Jerman), asam klorida ( $\mathrm{HCl}$ ) (Merck, Jerman), tris base (Merck, Jerman), natrium hidroksida $(\mathrm{NaOH})$ (Merck, Jerman), bromtimol biru, dan kalsium klorida $\left(\mathrm{CaCl}_{2}\right)$ (Merck, Jerman), asam urat (Merck Jerman), dan asam askorbat (Merck Jerman).

\section{Preparasi Sampel Biji Kacang Tolo (Zusfahair et al., 2018) \\ Biji kacang tolo ditimbang sebanyak} $10 \mathrm{~g}$ kemudian direndam dalam air kran selama 6 jam. Biji kacang tolo yang telah direndam kemudian digerminasi dalam gelap dengan menempatkan biji kacang tolo dalam wadah yang tertutup plastik hitam selama 8 hari dan diamati pertumbuhannya.

\section{Isolasi Enzim Urease Biji Kacang Tolo (Banerjee dan Aggarwal, 2012)}

Sebanyak $10 \mathrm{~g}$ kecambah biji kacang tolo dihaluskan menggunakan mortar dan pestle dalam keadaan dingin yaitu dengan mortar dan pestle yang telah disimpan dalam freezer. Kecambah yang telah dihaluskan lalu disuspensikan dalam $40 \mathrm{~mL}$ aseton $20 \%$ (v/v) dingin dan di-stirring dingin selama 3 jam. Suspensi setelah di-stirring, kemudian disaring menggunakan kain muslin, filtrat yang diperoleh disentrifus pada suhu $4{ }^{\circ} \mathrm{C}$ selama 15 menit dengan kecepatan $7000 \mathrm{rpm}$. Supernatan yang diperoleh merupakan ekstrak kasar enzim urease biji kacang tolo yang digunakan untuk membuat enzim amobil.

\section{Amobilisasi Urease dengan Alginat}

Amobilisasi enzim urease dari biji kacang tolo dilakukan dengan metode penjebakan menggunakan bahan pendukung alginat. Larutan alginat 5\% (b/v) untuk satu sampel dibuat dengan melarutkan $0.05 \mathrm{~g}$ alginat menggunakan sebanyak $0.25 \mathrm{~mL}$ pelarut bufer fosfat $0.002 \mathrm{M}$. Larutan alginat kemudian diaduk hingga larut dan selanjutnya larutan ditambah dengan ekstrak kasar urease sebanyak $0.75 \mathrm{~mL}$. Selama penambahan enzim pada larutan alginat dilakukan pengadukan secara perlahan. Pembuatan matriks alginat berbentuk beads dilakukan dengan cara memasukkan tetesan larutan alginat ke dalam larutan $\mathrm{CaCl}_{2}$ 0.2 M menggunakan mikropipet. Waktu interaksi yang digunakan untuk crosslinker dilakukan dengan cara merendam beads alginat dalam larutan $\mathrm{CaCl}_{2} \quad 0.2 \mathrm{M}$ selama 30 menit. Beads setelah direndam dengan $\mathrm{CaCl}_{2} 0.2 \mathrm{M}$ dibilas dengan akuades sehingga beads urease alginat siap untuk digunakan.

\section{Pengujian Urea}

Pengujian biosensor dilakukan dengan manganalisis larutan urea pada suatu seri konsentrasi 1, 2, 3, 4, dan $5 \mathrm{mM}$ dibuat dengan menggunakan pelarut akuades. Larutan standar urea sebanyak $2 \mathrm{~mL}$ ditambahkan beads urease alginat sebanyak $1 \mathrm{~mL}$ dan dibiarkan terjadi reaksi enzimatis selama 30 menit. Larutan hasil ditambah larutan indikator BTB $0.04 \%$ sebanyak $112.5 \mu \mathrm{L}$ setelah reaksi enzimatis selesai. Pengujian ini digunakan beads urease alginat yang direndam dalam akuades sebagai blanko. Langkah selanjutnya absorbansi larutan diukur menggunakan spektrofotometer UV-Vis pada panjang gelombang $616 \mathrm{~nm}$. Selisih absorbansi sampel dengan kontrol sebagai sumbu y dengan konsentrasi larutan uji sebagai sumbu $\mathrm{x}$ diplotkan menjadi kurva kalibrasi.

\section{Penentuan Waktu Reaksi Enzimatis}

Sampel urea yang digunakan adalah urea $4 \mathrm{mM}$. Reaksi enzimatis antara urea dengan beads urease alginat dioptimasi pada interval waktu 5 menit selama 35 menit dengan volume sampel urea yang diujikan sebanyak 2 $\mathrm{mL}$ dengan penambahan beads urease alginat sebanyak $1 \mathrm{~mL}$. Larutan hasil diuji sama dengan prosedur pada pengujian urea.

\section{Penentuan Linearitas dan Penentuan Batas Deteksi dan Batas Kuantifikasi}

Penentuan linearitas dan penentuan batas deteksi dan batas kuantifikasi dilakukan dengan menganalisis larutan urea konsentrasi $0.05 ; 1 ; 3 ; 7$; dan $15 \mathrm{mM}$ menggunakan beads urease alginat. Sampel urea yang diujikan sebanyak $2 \mathrm{~mL}$ dengan penambahan beads urease alginat sebanyak $1 \mathrm{~mL}$. Larutan hasil diuji sama dengan prosedur pada pengujian 
urea. Respon linear yang ditunjukkan melalui persamaan garis adalah sebagai berikut:

$$
y=b x+a
$$

dimana $b$ adalah slope atau kemiringan dari kurva kalibrasi, dan a adalah intersep atau perpotongan terhadap sumbu y. Hubungan linear dinyatakan dengan koefisien korelasi (r) pada kurva kalibrasi, dimana $r$ dapat mempunyai nilai dalam rentang $-1 \leq r \leq 1$.

Batas deteksi adalah jumlah terkecil analit dalam sampel yang dapat dideteksi yang masih memberikan respon signifikan dibandingkan dengan blanko. Batas deteksi merupakan parameter uji batas. Batas kuantifikasi merupakan parameter pada analisis renik dan diartikan sebagai kuantifikasi terkecil analit dalam sampel yang masih dapat memenuhi kriteria cermat dan seksama (Ravisankar et al., 2015).

$$
\begin{aligned}
& S y / x=\sqrt{\frac{\sum(Y-Y i)^{2}}{n-2}} \\
& L O D=\frac{3(S y / x)}{b} \\
& L O Q=\frac{10(S y / x)}{b} \\
& \text { Sy } / \mathrm{x}=\text { Simpangan baku } \\
& \text { LOD = Batas deteksi } \\
& \text { LOQ = Batas kuantifikasi } \\
& \mathrm{b}=\text { Slope }
\end{aligned}
$$

\section{Penentuan Keberulangan Analisis}

Uji keseksamaan (presisi) dilakukan untuk menentukan keberulangan analisis terhadap larutan urea $4 \mathrm{mM}$ yang direaksikan dengan beads urease alginat sesuai dengan prosedur amobilisasi urease dengan alginat yang dianalisis secara terus menerus. Analisis dilanjutkan sampai respon bersisa sekitar 50\%.

\section{Penentuan Keberulangan Pembuatan}

Uji ini dilakukan dengan menganalisis larutan urea konsentrasi $4 \mathrm{mM}$ yang dibuat pada kondisi percobaan yang sama. Keberulangan ditentukan dengan menghitung $\bar{x}$, standar deviasi (SD), persentase standar deviasi (\%RSD) atau koefisien variasi (KV). Persamaan yang digunakan sebagai berikut:

$$
\begin{aligned}
& S D=\sqrt{\frac{\sum(x-\bar{x})^{2}}{n-1}} \\
& \% R S D=\frac{S D}{\bar{x}} \times 100 \% \\
& K V=\frac{S D}{\bar{x}} \times 100 \%
\end{aligned}
$$

Nilai KV yang dihasilkan dibandingkan dengan nilai KV Horwitz yang diperoleh melalui persamaan berikut:

KV teoritik $=2^{(1-0,5 \log C)}$

$$
\text { HorRat }=\frac{K V \text { percobaan }}{K V \text { teoritik }}
$$

Nilai keberulangan yang dapat diterima adalah jika nilai Horwitz ratio (HorRat) yang diperoleh kurang dari 2.

\section{Pengujian Senyawa Pengganggu}

Asam askorbat $0.05 \mathrm{mM}$ dan asam urat $0.4 \mathrm{mM}$ (sebagai senyawa pengganggu) dicampurkan ke dalam larutan urea $4 \mathrm{mM}$, kemudian sebanyak $2 \mathrm{~mL}$ larutan urea $4 \mathrm{mM}$ ditambahkan beads urease alginat sebanyak 1 $\mathrm{mL}$ dan dibiarkan terjadi reaksi enzimatis selama 10 menit, selanjutnya ditambah larutan indikator BTB $0.04 \%$ sebanyak $112.5 \mu \mathrm{L}$ setelah reaksi enzimatis selesai. Pengujian ini digunakan akuades dengan beads urease biji kacang tolo sebagai blanko. Absorbansi larutan diukur menggunakan spektrofotometer UV-Vis pada panjang gelombang $616 \mathrm{~nm}$. Selisih absorbansi blanko dengan sampel diplotkan dalam grafik pengaruh asam askorbat dan asam urat. Hasil yang diperoleh dibandingkan dengan urea yang tidak ditambahkan dengan asam askorbat dan asam urat.

\section{HASIL DAN PEMBAHASAN} Amobilisasi Urease dengan Alginat

Pada amobilisasi menggunakan metode penjebakan tidak ada modifikasi biologi pada enzim sehingga aktivitas enzim ini lebih terjaga selama proses amobilisasi. Biosensor menggunakan enzim yang diamobilisasi dengan metode penjebakan 
sering ditandai dengan peningkatan stabilitas. Namun memiliki keterbatasan yaitu kemungkinan hambatan difusi dapat membatasi kinerja sistem (Sassolas et al., 2012).

Urease biji kacang tolo diamobilisasi dengan metode penjebakan menggunakan matrik pendukung alginat. Pemanfaatan alginat karena mempunyai beberapa keuntungan yaitu: non toksik, relatif tidak mahal, dan mudah pengerjaannya (Nasratun et al., 2009). Alginat adalah polisakarida anionik dan hidrofilik yang terjadi secara alami. Alginat merupakan salah satu bahan biosintesis yang paling melimpah dan terutama berasal dari rumput laut coklat dan bakteri. Natrium alginat adalah garam monovalen yang banyak digunakan karena kemampuan gelifikasi yang baik dengan adanya kation divalen $\mathrm{Ca}^{+2}$ (Sassolas et al., 2012). Garam natrium atau kalium dari asam alginat berbentuk larutan berair homogen kental diubah menjadi hidrogel ionotropik melalui ikatan silang dengan kation logam seperti $\mathrm{Ca}^{2+}, \mathrm{Sr}^{2+}$, atau $\mathrm{Ba}^{2+}$. Ikatan silang dari alginat disebabkan oleh chelation kation logam oleh kelompok karboksilat dari $\beta$-D-mannurate (M) dan $\alpha$-L-guluronate (G) residu alginat (Gambar 1) (Narayanan et al., 2012).

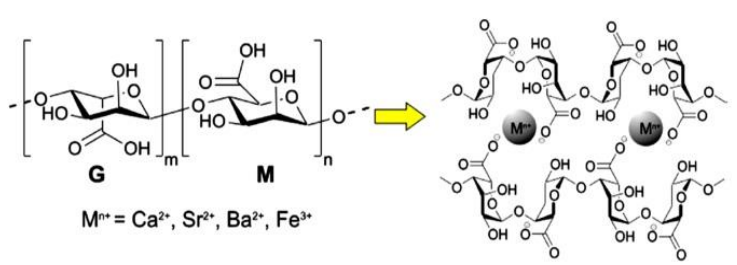

Gambar 1. Struktur asam alginat dan representasi skematik dari ikatan silang alginat dengan logam $\mathrm{M}^{\mathrm{n}+}$. (Narayanan et al., 2012).

\section{Pengujian Urea}

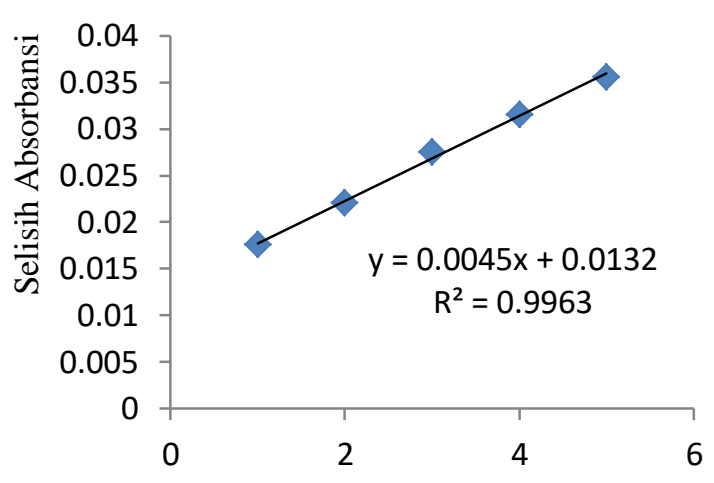

Konsentrasi urea $(\mathrm{mM})$

Gambar 2. Pengaruh konsentrasi urea terhadap respon pengukuran kadar urea,
Pada percobaan ini urea direaksikan dengan beads urease alginat menghasilkan amoniak yang selanjutnya ditambahkan indikator bromtimol biru (BTB) dan diukur absorbansi menggunakan spektrofotometer. Data pada Gambar 2 menunjukkan bahwa konsentrasi urea berbanding lurus dengan absorbansi. Persamaan regresi yang dihasilkan yaitu $\mathrm{y}=0.0045 \mathrm{x}+0.0132$, dengan kemiringan sebesar 0.0045 dan simpangan sebesar 0.0132 dengan nilai $\mathrm{R}^{2}$ sebesar 0.9963 . Respon yang linear pada pengujian urea menunjukkan bahwa produk reaksi yang dihasilkan dari reaksi urea dengan urease dari biji kacang tolo yang diamobilisasi dengan alginat dapat dideteksi menggunakan indikator BTB (Xie dan Suleiman, 1990). Pengembangkan sensor fiber optik urea berdasarkan pada penentuan secara enzimatik amoniak yang dihasilkan dari hidrolisis urea oleh urease yang diamobilisasi dengan indikator $\mathrm{pH}$ BTB. Pada percobaan ini dihasilkan kurva linear pada range $0.25-8 \mathrm{mM}$ dengan koefisien korelasi 0.9940.

\section{Penentuan Waktu Reaksi Enzimatis}

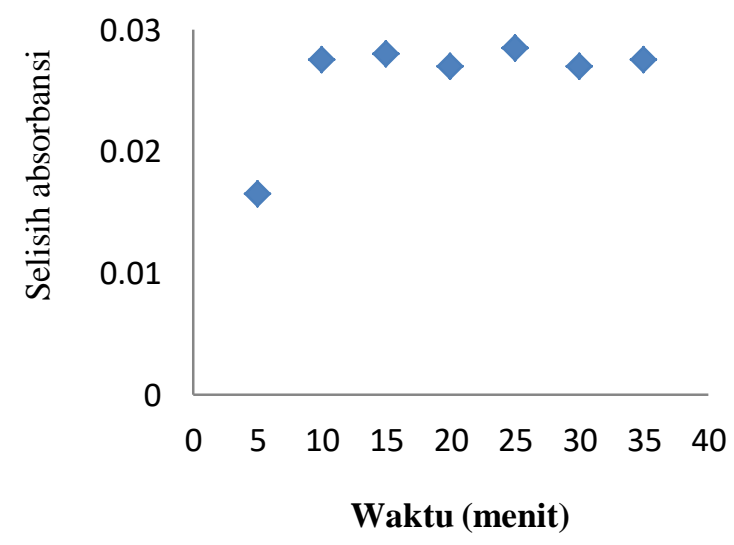

Gambar 3. Pengaruh waktu reaksi enzimatis terhadap selisih respon pengukuran

Berdasarkan data penelitian pada Gambar 3 menunjukkan respon meningkat tajam dari waktu 5 - 10 menit dan selanjutkan menunjukkan respon yang stabil sampai waktu 35. Disimpulkan urea $4 \mathrm{mM}$ yang direaksikan dengan urease dari biji kacang tolo yang diamobilisasi dengan alginat menghasilkan amoniak yang optimum pada waktu 10 menit. Waktu inkubasi 10 menit digunakan untuk penelitian selanjutnya. (Fauziyah, 2012) menyatakan biosesensor urea berbasis 
amobilisasi urease dalam membran polianilin memperoleh sinyal yang tidak mengalami perubahan yang berarti mulai waktu 20 menit.

\section{Penentuan linearitas}

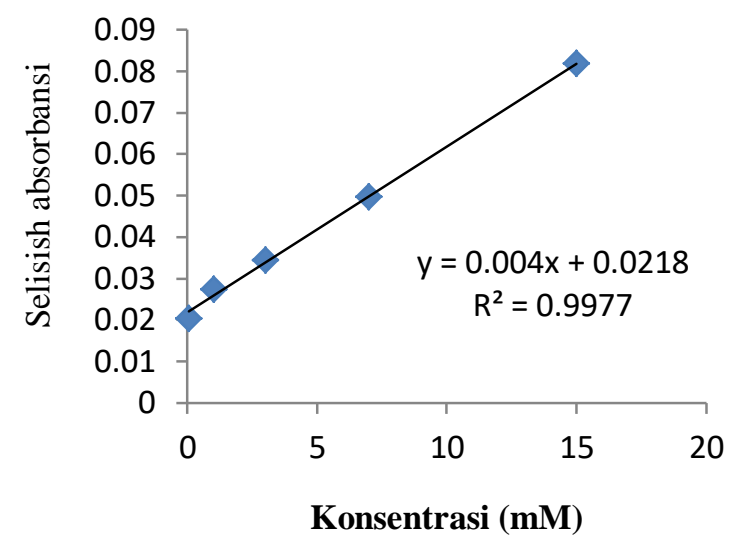

Gambar 4. Kurva linearitas pengukuran urea

Gambar 4 memperlihatkan bahwa kurva linearitas pengukuran urea menunjukkan hubungan yang linear antara konsentrasi urea dengan selisih absorbansi pada rentang konsentrasi urea $0.05 \mathrm{mM}$ sampai dengan 15 $\mathrm{mM}$. Persamaan regresi yang diperoleh dari kurva standar adalah $\mathrm{y}=0.004 \mathrm{x}+0.0218$ dengan koefisien korelasi (r) sebesar 0.9981 dan koefisien determinasi $\left(\mathrm{r}^{2}\right)$ sebesar 0.9977. Nilai koefisien korelasi (r) dan koefisien determinasi $\left(\mathrm{r}^{2}\right)$ mendekati 1 menunjukkan bahwa beads urease biji kacang tolo memberikan respon linear pada rentang konsentrasi tersebut. Biosensor urea berbasis urease rekombinan yang diamobilisasi dengan nanopartikel silicalite mempunyai rentang linear dari 0.5-15 mM (Velychko et al., 2016), sedangkan biosensor fiber optik urea berbasis pengukuran absorbsi memiliki rentang linearitas $0.25-8 \mathrm{mM}$ (Xie dan Suleiman, 1990). Perbedaan nilai ini disebabkan karena perbedaan kemurnian enzim. Kemurnian enzim menentukan nilai konstanta Michaelis Menten $(\mathrm{Km})$ dan selanjutnya mempengaruhi kinerja biosensor.

\section{Penentuan batas deteksi (Limit of Detection) (LOD) dan batas kuantifikasi (Limit of Quantification) (LOQ)}

Berdasarkan hasil perhitungan menunjukkan bahwa nilai simpangan baku yang diperoleh sebesar 0.0010083 dengan nilai LOD yang diperoleh dari hasil pengujian sebesar $0.8 \mathrm{mM}$ dan LOQ sebesar $2.67 \mathrm{mM}$.
Hal ini berarti bahwa jumlah terkecil analit yang masih dapat dideteksi dalam sampel oleh beads urease alginat sebesar $0.8 \mathrm{mM}$. Kuantifikasi terkecil zat yang masih dapat memenuhi kriteria cermat dan seksama dalam sampel sebesar $2.67 \mathrm{mM}$.

\section{Penentuan keberulangan analisis}

Keberulangan analisis dilakukan dengan mereaksikan antara beads urease alginat dengan larutan urea $4 \mathrm{mM}$. Blanko yang digunakan adalah beads urease alginat yang direndam dalam akuades.

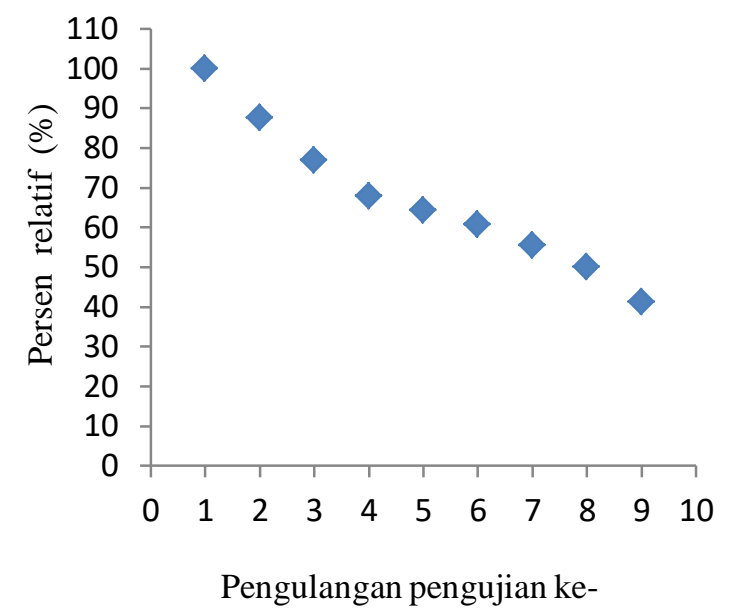

Gambar 5. Grafik hasil pengulangan analisis

Berdasarkan Gambar 5 menunjukkan respon biosensor menurun setelah digunakan berulang kali dan nilai respon relatif bersisa $50 \%$ setelah digunakan 8 kali. Stabilitas enzim tergantung pada metode amobilisasi enzim yang digunakan. Keuntungan metode penjebakan adalah penurunan aktivitasnya lebih kecil dibandingkan metode adsorpsi. (Fauziyah, 2012) melakukan penelitian biosensor urea berbasis amobilisasi urease dalam membran polianilin diperoleh absorbansi pengukuran urea menurun setelah digunakan dan pada pemakaian ke-7 absorbansi yang diberikan analit sudah mendekati absorbansi blanko. Menurut (Zusfahair et al., 2017) permukaan beads enzim sebelum digunakan bergelombang menyebabkan luas permukaan lebih tinggi sehingga kontak enzim dengan substrat lebih banyak. Permukaan beads enzim setelah digunakan lebih rata. Hal ini menyebabkan enzim yang berada dipermukaan matrik terkikis sehingga jumlah enzim yang berkontak dengan substrat lebih sedikit. Hal ini 
menyebabkan beads enzim memiliki respon yang menurun.

\section{Penentuan Keberulangan Pembuatan}

Penentuan keberulangan pembuatan beads urease alginat dilakukan dengan membuat 10 buah beads urease alginat dalam keadaaan yang sama. Semua beads tersebut digunakan untuk mengukur kadar urea dengan konsentrasi $4 \mathrm{mM}$.



Gambar 6. Grafik keberulangan pembuatan

Hasil respon keberulangan pembuatan menunjukkan respon yang berbeda sehingga diperlukan suatu analisis lebih lanjut, yaitu dengan mencari nilai $\bar{x}$, SD, RSD, \%RSD dan nilai Horwitz ratio (HorRat)nya untuk dapat mengetahui apakah data tersebut dapat diterima atau tidak. Berdasarkan hasil perhitungan beads urease alginat menghasilkan nilai $\bar{x}$ sebesar 0.0291; nilai SD sebesar 0.0017; nilai RSD sebesar 0.0594; nilai \%RSD sebesar $5.94 \%$ dan nilai HorRat nya sebesar 0.75. Berdasarkan hubungan antara konsentrasi dengan RSD untuk konsentrasi $4 \mathrm{mM}$ memiliki nilai maksimal RSD sebesar 8 (Riyanto, 2014). Berdasarkan nilai RSD dan nilai HorRat keberulangan pembuatan beads urease alginat masih dapat diterima.

\section{Pengujian Senyawa Pengganggu}

Senyawa penganggu adalah senyawa yang terdapat dalam darah yang mungkin akan mengurangi ketelitian penentuan urea karena dapat mengubah $\mathrm{pH}$ seperti asam askorbat dan asam urat. Konsentrasi asam askorbat dalam darah normal sekitar $50 \mu \mathrm{M}$ dan konsentrasi asam urat dalam darah normal sekitar 380-400 $\mu \mathrm{M}$ (Fatoni et al., 2013). Hasil pengujian menunjukkan bahwa dengan penambahan asam askorbat $0.05 \mathrm{mM}$ dan asam urat $0,4 \mathrm{mM}$ pada urea $4 \mathrm{mM}$ tidak menunjukkan respon yang berbeda pada biosensor (Gambar 7). Hal ini juga telah dinyatakan oleh Widihastono (1993) bahwa penambahan asam askorbat $0.005 \mathrm{mM}$ dan asam urat $0.2 \mathrm{mM}$ dalam analisis kadar urea menggunakan enzim urease dengan elektroda tungsten tidak mempengaruhi hasil pengujian kadar urea.

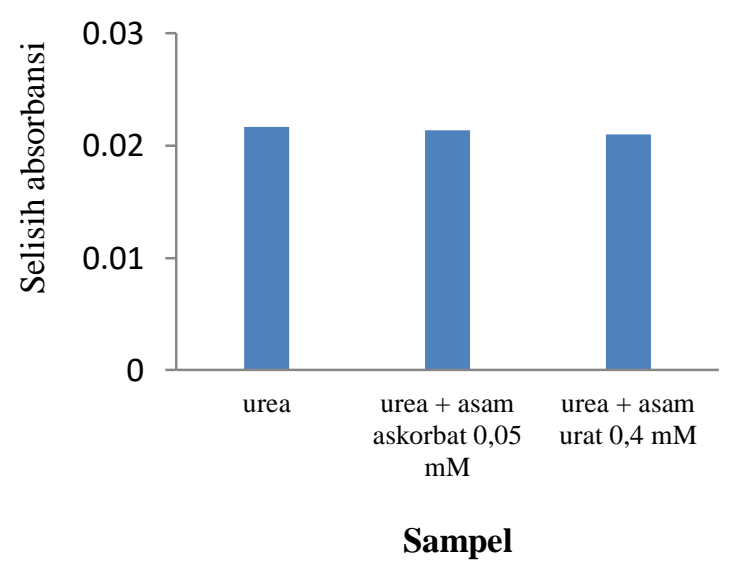

Gambar 7. Grafik pengujian senyawa pengganggu

\section{SIMPULAN}

Kadar urea dapat ditentukan dengan membuat beads urease alginat dengan konsentrasi alginat $5 \%$ perbandingan urease biji kacang tolo dengan bufer fosfat $0.002 \mathrm{M}$ (3:1) dan kadar $\mathrm{CaCl}_{2}$ 0.2 M. Beads urease alginat direaksikan dengan larutan urea konsentrasi $4 \mathrm{mM}$ memiliki respon yang baik sampai 8 kali (respon $\geq 50 \%$ ), dan keberulangan pembuatan 10 kali dengan RSD 6\%. Sensitivitas beads urease alginat ini baik karena hasil analisis kadar urea tidak terpengaruh oleh senyawa pengganggu, yaitu asam askorbat $0,05 \mathrm{mM}$ dan asam urat 0.4 $\mathrm{mM}$. Jangkauan dari biosensor ini linier pada konsentrasi $0.05-15 \mathrm{mM}$ dengan nilai $\mathrm{y}=$ $0.004 \mathrm{x}+0.0218$; nilai $\mathrm{r}^{2}=0.9977$. LOD dan LOQ yang diperoleh sebesar $0.8 \mathrm{mM}$ dan 2.67 $\mathrm{mM}$.

\section{UCAPAN TERIMA KASIH}

Penelitian dilaksanakan atas bantuan dana penelitian Riset Unggulan Unsoed tahun anggaran 2018 berdasarkan Surat Keputusan Ketua LPPM UNSOED No: Kept. 2350/UN23.14/PN.01.00/2018.

\section{DAFTAR PUSTAKA}

Andrich L, Esti M, Moresi M. 2010. Urea degradation in some white wines by 
immobilized acid urease in a stirred bioreactor. J. Agric. Food Chem. 58: 6747-6753.

https://doi.org/10.1021/jf1006837

Banerjee S, Aggarwal A. 2012. Isolation, partial purification, characterization and inhibition of urease. Asian Journal of Bio Science. 7(2): 203-209.

Eghbali M, Farahbakhsh A. 2015. Urea biosensor based on immobilization of urease on $\mathrm{ZnO}$ nanoparticles. Oriental Journal of Chemistry. 31(2): 1237-1242.

Fatoni A, Numnuam A, Kanatharana P, Limbut W, Thammakhet C, Thavarungkul P. 2013. A highly stable oxygen-independent glucose biosensor based on a chitosan-albumin cryogel incorporated with carbon nanotubes and ferrocene. Sensors and Actuators, B: Chemical. 185: 725-734. https://doi.org/10.1016/j.snb.2013.05.056

Fatoni A, Numnuam A, Kanatharana P, Limbut W, Thavarungkul P. 2014. A conductive porous structured chitosan-grafted polyaniline cryogel for use as a sialic acid biosensor. Electrochimica Acta. 130: 296304.

https://doi.org/10.1016/j.electacta.2014.03. 036

Fauziyah B. 2012. Optimasi parameter analitik biosensor urea berbasis immobilisasi urease dalam membran polianilin. Sainstis. 1(1): $65-76$.

Kale PD, Bodade AB, Chaudhari GN. 2016. Study of immobilization of urease on PVANANO $\mathrm{NiFe}_{2} \mathrm{O}_{4}$ nanocomposite for biosensor application. International Journal of Pharmacy and Pharmaceutical Sciences. 8(7): 4-9.

Narayanan RP, Melman G, Letourneau NJ, Mendelson NL, Melman A. 2012. Photodegradable iron(III) cross-linked alginate gels. Biomacromolecules. 13: 2465-2471.

Nasratun M, Said HA, Noraziah A, Alla ANA. 2009. Immobilization of lipase from Candida rugosa on chitosan beads for transesterification reaction. Faculty of Computer Systems and Software Engineering, Faculty of Electrical and Electronic Engineering. American Journal of Applied Sciences. 6(9): 1653-1657.
Ravisankar P, Navya CN, Pravallika D, Sri DN. 2015. A review on step-by-step analytical method validation. IOSR Journal Of Pharmacy. 5(10): 7-19.

Riyanto. 2014. Validasi \& Verifikasi Metode Uji Sesuai dengan ISO IEC 17025. Laboratorium.

Saeedfar K, Heng LY, Ling TL, Rezayi M. 2013. Potentiometric urea biosensor based on an immobilised fullerene-urease bioconjugate. Sensors. 13: 16851-16866. https://doi.org/10.3390/s131216851

Sassolas A, Blum LJ, Leca-bouvier BD. 2012. Immobilization strategies to develop enzymatic biosensors. Biotechnology Advances. $\quad 30(3)$ : 489-511. https://doi.org/10.1016/j.biotechadv.2011. 09.003

Shimada T, Hasegawa T. 2017. Determination of equilibrium structures of bromothymol blue revealed by using quantum chemistry with an aid of multivariate analysis of electronic absorption spectra. Spectrochimica Acta Part A: Molecular and Biomolecular Spectroscopy. 131.https://doi.org/10.1016/j.saa.2017.05.04 0

Velychko TP, Soldatkin OO, Melnyk VG, Marchenko SV, Kirdeciler SK, Akata B, Soldatkin AP. 2016. A novel conductometric urea biosensor with improved analytical characteristic based on recombinant urease adsorbed on nanoparticle of silicalite. Nanoscale Research Letters. 11(106): 1-6. https://doi.org/10.1186/s11671-016-13103

Verma N, Kumar R, Sachin M. 2012. Simple , qualitative cum quantitative, user friendly biosensor for analysis of Urea. Advances in Applied Science Research. 3(1): 135141.

Widihastono B. 1993. Biosensor untuk analisis urea berdasarkan pada aplikasi enzim urease dan elektroda tungsten. JKTI. 3(1): 26-32.

Xie X, Suleiman AA. 1990. A urea fiber optic biosensor based on absorption measurement. Analytical Letters. 23(12): 2143-2153. https://doi.org/10.1080/000327190080525 56 
Yi Z, Wang H, Chen K, Gao Q, Tang H, Yu R, Chu X. 2014. Biosensors and bioelectronics a novel electrochemical biosensor for sensitive detection of telomerase activity based on structure-switching DNA. Biosensors and Bioelectronics Journal. 53: 310-315. https://doi.org/10.1016/j.bios.2013.09.072

Zusfahair, Ningsih DR, Fatoni A, Putri D. 2018. Partial purification and characterization of urease from black-eyed pea ( Vigna unguiculata ssp unguiculata L . ). Malaysian Journal of Fundamental and Applied Sciences. 14(1): 20-24.

Zusfahair, Ningsih DR, Kartika D, Fatoni A, Permatawati I. 2017. Amobilisasi dan karakterisasi amilase dari bakteri Bacillus thuringiensis HCB6 dalam matriks kalsium alginat immobilization. Molekul. 12(1):

71-79. https://doi.org/10.20884/1.jm.2016.11.2.24 2 